\title{
同種抗体産生予防に括ける白血球除去フィルターの効果について
}

\author{
安田広康 大戸 斉遠山ゆり子 \\ 阿部 力哉1) 菊田 敦2) 丸山 幸夫²) \\ 大河原千恵 ${ }^{4)}$ 神林 裕行 松田 信5) \\ ${ }^{1)}$ 福島県立医科大学附属病院輸血部， ${ }^{2}$ 同 小坚科， ${ }^{31}$ 同 第 1 内科 \\ 4)太田西の内病院輸血管理室, ${ }^{5}$ 同 血液疾患センター
}

(平成 3 年 2 月 12 日受付)

\section{EFFECTIVE PROPHYLAXIS AGAINST THE DEVELOPMENT OF ALLOANTIBODIES WITH LEUKOCYTE-DEPLETED BLOOD COMPONENTS BY FILTRATION}

\author{
Hiroyasu Yasuda, Hitoshi Ohto, Yuriko Tohyama, Rikiya Abe ${ }^{1)}$, Atushi Kikuta ${ }^{2)}$, \\ Maruyama Yukio ${ }^{3)}$, Chie Ohkawara ${ }^{4)}$, Hiroyuki Kanbayashi and Shin Matsuda ${ }^{5)}$ \\ Blood Transfusion Service ${ }^{1)}$, Department of Pediatrics ${ }^{2)}$, First Department of Internal Medicine ${ }^{3)}$, \\ Fukushima Medical College \\ Blood Transfusion Service4), Center For Hematopoietic Diseases ${ }^{5)}$, Ohta-Nishinouchi Hospital
}

In a retrospective study we investigated the development and the course of alloimmunization after leukocyte-depleted blood component transfusion using leukocyte filters in 89 patients. These 89 patients who had negative lymphocytotoxic antibodies secreening on admission were classified into four groups. In the 1st group (I) without tansfusion history, who received leukocyte-depleted blood components, three (12.5\%) of 24 patients developed lymphocytotoxic antibodies, compared with twelve (46.2\%) of 26 patients in the 2nd group (II) receiving one or more units of blood components with leukocytes $(\mathrm{p}<0.01)$. Further, the $3 \mathrm{rd}$ (III) and the 4 th group (IV) with previous transfusions showed a significantly higher incidence of antibodies of $44.4 \%$ and $42.8 \%$, respectively, despite continuation of leukocyte-depleted transfusion, compared to that of the group (I).

We observed a marked decrease in alloimmunization rate in patients who were transfused with leukocyte-depleted blood components. These results indicate that we can expect the effective prophylaxis against alloimmunization by using leukocyte-poor blood components with filtration in patients without previous transfusion and pregnancies.

\section{緒 言}

輸血は, 再生不良性貧血や白血病などの血液疾 患に颃いて, 貧血及び出血傾向の改善のために欠 くことのできない補充療法のひとつである。しか し，ランダムドナー由来の血液製剤の使用により しばしば非溶血性発熱反応や血小板輸血不応状態 などを起こし, 結果として輸血が治療をより困難 にする場合もある。これらの副作用には, 抗 HLA 抗体や抗顆粒球抗体が主に関与し ${ }^{122}$, 製剤中に混 入する白血球分画が輸注されることにより同種免 疫が誘導された結果，これらの抗体が産生される
ものと考えられている3.
今回私達は, フィルターを用い免疫源となる同 種白血球を血液製剂から除去することにより，抗 HLA 抗体産生がどの程度抑制されるかを retrospective に検討したので報告する。

\section{対}

1987年 6 月から1990年 5 月までの 3 年間に当院 および関連病院に入院し, 当輸血部に輸血検查依 頼のあった血液疾患患者89例を対象とした。内訳 は，急性非リンパ性白血病（ANLL）39例，急性 リンパ性白血病（ALL）15例，再生不良性貧血 
（AA） 9 例, 慢性骨髄性白血病おょび急性転化 （CML \& CML-BC） 8 例, 骨髄異形成症候群 （MDS） 4 例，悪性リンパ腫（ML） 3 例，慢性リ ンパ性白血病 (CLL) 1 例, その他10例であった。 なお，輸血歴及び妊娠歴が不明なもの，または スクリーニング時にすでに抗 HLA 抗体を保有し ていた症例は対象から除外した。

\section{方 法}

1. 血液製剂からの白血球除去

1）白血球除去赤血球製剂：フィルター素材に 超微細ポリェステル不織布を用いた SEPACELL R-500A（旭メディカル社）及び cotton woolを用 いた Imugard IG-400Y（テルモ社）によりベッド サイドにて調製した。

2）白血球除去血小板製剂：Imugard IG-400Y （テルモ社）によりベッドサイドにて調製した。

2. 抗 HLA 抗体の検出, 判定法

18人のパネルリンパ球を target cell として，リ ンパ球細胞毒試験（LCT）により検出した。 LCT は NIH の標準法に準じて行い, score 4以上（死 細胞 $21 \%$ 以上）を陽性とした。なお，パネルリン 八球には HLA-A，B，C 各 locusに拈いて，抗原 頻度の高いものから順に同一抗原が 2 つ以上重な るように工夫したものを用意した（表 1 ）.

\section{結 果}

対象を初診時に扔ける輸血歴および白血球除去 製剂の使用の有無から I 〜 IV群に分類し比較検討 した。

I 群：輸血歴がなく白血球除去製剤のみ使用し た群

II 群：輸血歷はないが 1 単位以上の白血球を除 去しない製剂を使用した群

III群：輸血歴はあるが白血球除去製剤の久使用
表 1 パネルリンパ球

\begin{tabular}{|c|c|c|c|c|c|c|c|}
\hline \multirow{3}{*}{$\begin{array}{c}\text { Cell No. } \\
\text { FT } 43\end{array}$} & \multicolumn{7}{|c|}{ HLA } \\
\hline & \multicolumn{3}{|c|}{ A locus } & \multicolumn{2}{|c|}{ B locus } & \multicolumn{2}{|c|}{ C locus } \\
\hline & & & A 24 & Bw55 & Bw59 & Cw1 & \\
\hline FT188 & & & A 24 & Bw54 & Bw60 & Cw1 & Cw10 \\
\hline FT147 & A & 2 & A 24 & Bw48 & Bw60 & & Cw9 \\
\hline FT 18 & A & 2 & A 24 & В 39 & Bw52 & & $\mathrm{Cw} 7$ \\
\hline FT 1 & A & 2 & & B 35 & B 51 & & $\mathrm{Cw} 7$ \\
\hline FT129 & A & 2 & & B 7 & Bw61 & Cw7 & Cw9 \\
\hline FT 80 & A & 2 & & B 13 & Bw46 & Cw10 & Cw11 \\
\hline FT 57 & A & 2 & A 11 & Bw62 & & $\mathrm{Cw} 4$ & $\mathrm{Cw} 10$ \\
\hline FT148 & A & 2 & A 11 & B 35 & Bw54 & Cw1 & Cw9 \\
\hline FT189 & A & 2 & A 11 & Bw46 & Bw48 & & Cw11 \\
\hline FT 35 & & & A 11 & Bw52 & Bw62 & $\mathrm{Cw} 4$ & \\
\hline FT 79 & A & 24 & A 11 & Bw52 & Bw67 & & Cw7 \\
\hline FT113 & A & 26 & A 11 & Bw61 & Bw62 & & Cw9 \\
\hline FT 27 & A & 26 & A 24 & B 7 & B 35 & Cw7 & Cw9 \\
\hline FT 65 & A & 26 & Aw33 & B 44 & Bw59 & Cw1 & \\
\hline FT 15 & A & 24 & Aw33 & B 44 & Bw55 & Cw1 & \\
\hline FT 34 & A & 2 & A 31 & В 39 & B 51 & & $\mathrm{Cw} 7$ \\
\hline FT146 & A & 2 & A 26 & B 13 & Bw56 & $\mathrm{Cw} 7$ & Cw10 \\
\hline
\end{tabular}

\section{した群}

IV群：輸血歷があり 1 単位以上の白血球を除去 しない製剤を使用した群

各群の抗 HLA 抗体陽性率を表 2 に示した。輸 血歷のない群で, かつ白血球除去製剤のみを使用 した I 群の抗体陽性率は24症例中 3 例 (12.5\%)

と, 1 単位以上の白血球を除去しない製剤を使用 したII群の26症例中12例 (46.2\%) に比し，有意 （ $\mathrm{p}<0.01 ） の$ 低值を認めた。これに対し, 輸血歴 のあったIII, IV 群ではそれぞれ18症例中 8 例 (44.4\%)，21症例中 9 例 (42.8\%) と白血球除去 の有無にかかわらず抗体陽性率に差は認められな かった。 また，III群は $44.4 \%$ と白血球除去製剤の みを使用した I 群に比し, 有意 $(\mathrm{p}<0.025)$ に高 い陽性率を認めた。

表 2 対象群拈よび抗体陽性率

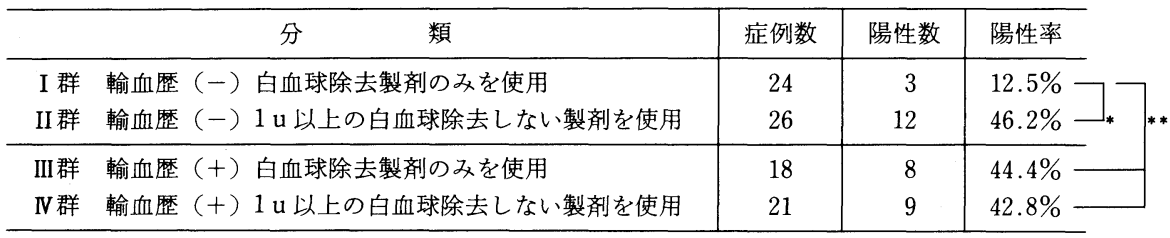

${ }^{*} \mathrm{P}<0.01 \quad{ }^{* *} \mathrm{P}<0.025$ 
表 3 各群に括ける対象の比較

\begin{tabular}{|c|c|c|c|c|}
\hline & I & II & III & N \\
\hline \multicolumn{5}{|l|}{ 性別 } \\
\hline 男 & 12 & 15 & 6 & 11 \\
\hline 女 & $12(8)$ & $11(9)$ & $12(9)$ & $10(7)$ \\
\hline \multicolumn{5}{|l|}{ 年齢 } \\
\hline 中央値 & 52 & 53 & 59 & 52 \\
\hline 範囲 & $3-86$ & $4-87$ & $21-77$ & $23-70$ \\
\hline 急性非リンパ性白血病 & 9 & 12 & 10 & 8 \\
\hline 急性リンパ性白血病 & 5 & 4 & 1 & 5 \\
\hline 再生不良性白血病 & 2 & 1 & 2 & 4 \\
\hline 慢性骨髄性白血病 - 急性転化 & 0 & 4 & 3 & 1 \\
\hline 骨䯣異形成症候群 & 2 & 0 & 1 & 1 \\
\hline 悪性リンパ腫 & 1 & 2 & 0 & 0 \\
\hline 慢性リンパ性白血病 & 0 & 0 & 1 & 0 \\
\hline その他 & 5 & 3 & 0 & 2 \\
\hline
\end{tabular}

表 4 輸血製剂使用期間及び輸血総白血球数

\begin{tabular}{r|c|c|c|c}
\hline \multirow{2}{*}{} & \multicolumn{2}{|c|}{ 輸血用血液製剂使用期間(月) } & \multicolumn{2}{c}{ 輸血総白血球数 $\left(\times 10^{9}\right)$} \\
\cline { 2 - 5 } & 中央値 & 範 囲 & 中央値 & 範 囲 \\
\hline I 群 & 4.4 & $1.5-10.7$ & 1.1 & $0.1-5.0$ \\
II 群 & 6.4 & $1.7-21.0$ & 5.8 & $0.9-44.6$ \\
III群 & 3.0 & $1.0-10.0$ & 1.2 & $0.1-7.0$ \\
IV 群 & 4.0 & $1.4-22.7$ & 5.1 & $0.9-24.7$ \\
\hline
\end{tabular}

表 5 各製剤 1 単位あたりの平均白血球数 $\left(\times 10^{9}\right)$

\begin{tabular}{ll|c}
\hline \multicolumn{1}{c|}{ 製 } & 剂 & 白血球数の平均 \\
\hline 濃厚赤血球 & & 1.24 \\
洗浄赤血球 & & $0: 48$ \\
白血球除去赤血球 & $\mathrm{R}-500 \mathrm{~A}$ & 0.012 \\
& $\mathrm{IG}-400 \mathrm{Y}$ & 0.074 \\
濃厚血小板 & & 0.014 \\
白血球除去血小板 & $\mathrm{IG}-400 \mathrm{Y}$ & 0.001 \\
\hline
\end{tabular}

対象の各群に打ける男女比, 年齢及び妊娠歷の ある症例は同程度に存在し，また各種血液疾患も ほぼ同率に分散していた(表 3 )。輸血用血液製剂 の使用期間は, II 群で 6.4 カ月と他の群の3.0 4.4 カ月に比してやや長かったものの, 輸血総白血球 数についてはフィルター使用群( I とIII群), 未使 用群（II とIV群）との間に差を認めなかった（表 4 )。な括，輸血総白血球数は，既報の製剂別の平

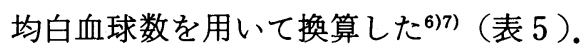

\section{考 察}

同種免疫応答に主要組織適合抗原である HLA が密接に関与していることは周知の事実である. また, 輸血が一種の臓器移植と考えられているの も膜抗原の 1 つとして HLA を有する白血球が多 少なりとも成分製剤中に混入しているからであ る. 例えば, 濃厚赤血球 1 単位中には $10^{9}$ 個オー ダーの白血球（主に顆粒球）が，またランダムド ナー由来濃厚血小板10単位中には $10^{8}$ 個のオー ダーの白血球 (主にリンパ球) が残存している4)8 Claas $^{5}$ や Minami9) らは，血小板製剂の頻回輸 血により産生される抗 HLA 抗体産生には, 輸血 される血小板そのものよりも血小板浮遊液中に混 入している白血球, 特にClass II 抗原陽性細胞に 依存することを，マウスに括ける抗 LCT 抗体産 生及び混合リンパ球反応 (MLR) などの実験から 証明した。ささに，一次免疫応答には抗原特異的 helper-T 細胞による同種抗体産生, 抗原特異的 $\mathrm{T}$ 細胞増殖に伴う細胞障害性の誘導が不可欠であ り,これには class II 抗原陽性細胞の存在が有効 かつ重要であるといら ${ }^{910)}$. 従って, 混入する白血 球, 特に B 細胞や単球が様々な同種免疫応答の引 き金と成り，輸血に伴なら様々な非溶血性輸血副 作用をむたらしているものと考える。中でも，同 種抗体，特に抗 HLA 抗体は混入して輸血される 白血球や血小板と反応し，発熱反応や血小板輸血 不応状態などの主な原因の 1 つであり，これらの 細胞を効率よく除去することにより同種免疫は抑 制されるものと思われる.Vakkila と Myllylä ら ${ }^{11)}$ は，赤血球製剤や血小板製剤を Imugard IG500で処理したろ過血液中の細胞分画を各種表面 マーカーを用いた Flow-cytometry 法により検討 している。それによると，白血球除去赤血球製剂 中の白血球の $60 \sim 70 \%$ は顆粒球であり, 残りの 30 ５0\%は $\mathrm{T}$ 細胞であったのに対し，単球及び $\mathrm{B}$ 細胞は $2 \%$ 以下であった。 また白血球除去血小板 製剂中の $85 \sim 98 \%$ $\mathrm{T}$ 細胞であり, B 細胞及び単 球はそれぞれ $3 \%$ 以下，0\%であったといら。

今回，我々は，白血球除去フィルターを用いた 血液製剂の使用により，抗体産生能がどの程度抑 制されるかを，抗 HLA 抗体陽性率から検討した。 
輸血歴がなく白血球除去製剤のみを使用した I 群 において $12.5 \%$ と，対照であるII群の $46.2 \%$ に比 し抗体陽性率に有意の低值を認めた。この結果は, Murphy（1986）ら ら年の対照群15/31（48\%）に対 して白血球除去群での3/19 (16\%), Sniecinski (1986）ら ${ }^{13)}$ の10/20 (50\%) に対し $3 / 20$ (15\%), Andreu (1988) ら ${ }^{14)}$ क $11 / 35(31.4 \%), 4 /$ $34(11.7 \%)$ と, 白血球除去にフィルターを用い た諸家らの報告に一致するものであった。このこ とは, 白血球の混入する血液製剤から白血球のみ を一定レベルまで除去することにより，HLA 抗 原に対する同種免疫誘導を抑制し得ることを意味 している.これまでの報告では, 0.5 1×107以下 のレベルまで除去すれば, 非溶血性発熱反応や抗 HLA 抗体による血小板輸血不応状態はほぼ認め られなくなるといら ${ }^{13) 15) ~ 17) . ~}$

次に，輸血歴のあったIII群で，I 群同様に白血 球除去製剂のみを使用したにもかかわらず高い抗 体陽性率を認めたことは，過去に輸血や妊娠など 同種抗原により感作された症例にはもはや白血球 除去製剂の効果は期待でさない可能性がある。一 方, Sniecinski らは, 同種抗原で暴露された群で も白血球除去製剂の使用によりコントロール群と 同程度に陽性率が低下し，フィルターによる免疫 抑制効果を認めたとしている ${ }^{13)}$.これに対し, 感作 後に引き起こされる二次免疫応答にはもはや混入 している class II 抗原陽性細胞の存在は必須では なく, pureな血小板のみでも十分に同種抗体（抗 class I 抗体）産生を誘導しらるといら報告もあ $り^{3) \sim 5)}$, 我々の結果もこれを支持する. とはいえ, 既に同種抗体が産生されている症例に対しても非 溶血性発熱反応を防止する目的から，依然として フィルター使用の意義は大きいと言える。

以上, 同種免疫予防の観点から, 今後頻回輸血, 特に血小板輸血によりサポートすることが予測さ れる症例においては, 輸血開始時から積極的に フィルターを使用することが望まれる。

\section{結語}

1）輸血歷がなく白血球除去製剂のみを使用し た群の抗 HLA 抗体陽性率は他の群に比し, 有意 に低頻度であることを認めた。
2）輸血歷のある症例には，白血球除去フィル ターの効果は低くなるので, 頻回輸血が必要とさ れる症例への輸血に際しては, 同種抗体産生予防 の観点から当初より白血球除去製剂の使用が有用 である。

\section{文献}

1）大戸 斉, 遠山 博, 鈴木征子：二種類の血小板 輸血による抗 HLA 抗体産生の検討. 埼玉医大誌, $15: 139-143,1988$.

2）神林裕行, 大戸 斉, 刈米重夫, 田中鉄五郎：血 液疾患患者に打ける LCT 法に上る抗 HLA 抗体 の検討. 臨床血液, $30: 815-822,1989$.

3）池田康夫, 半田 誠: 血液製剂からの白血球の除 去. Immunohaematology, $11: 145-152,1989$.

4）天木一太：輸血に上る同種免废を予防する白血球 除去一日本輸血学会第 90 回関東支部例会上り一. Immunohaematology, 12 : 150-157, 1990.

5) Class, F.H.J., Smeenk, R.J.T., Schmidt, R., et al.: Alloimmunization against the MHC antigens after platelet transfusions is due to contaminating leukocytes in the platelet suspension. Exp. Haematol., 9: 84-89, 1981.

6）高本 滋：血液製剂の使い使い方。臨床医，14： 180-182, 1988.

7）長谷川秀弥，関口定美：血液事業， $13 ： 17-23$, 1990.

8) Sekiguchi, S. and Takahashi, T.A.: Leukocyte-depleted blood products and their clinical usefulness. In Brozovic, B.ED.: The role of leukocyte depletion in blood transfusion practice. Proceedings of the International workshop 1988, Blackwell Scientific Publications, Oxford, U.K., 1989.

9) Minami, M. and Shreffler, D.C.: Ia-positive stimulator cells are required in primary, but not in secondary mixed leukocyte reactions against $\mathrm{H}-2 \mathrm{k}$ and $\mathrm{H}-2 \mathrm{~d}$ differences. J. Immunol., 126: 1774-1779, 1981.

10) Frangoulis, B., Besluau, D., Chopin, M., et al. : Immune response to $\mathrm{H} \cdot 2$ class I antigens on platelets. I. Immunogenecity of platelet class I antigens. Tissue Antigens, 32 : 46-54, 1988.

11) Vakkilla, J. and Myllyllä, G.: Amount and type of leukocytes in 'Leukocyte-free' red cell and platelet concentrates. Vox Sang, 53: 76 $-82,1987$.

12) Murphy, M.F., Metcalfe, P., Thomas, H., et al. : Use of leukocyte-poor blood components and HLA-matched platelet donors to prevent HLA alloimmunization. Br. J. Haematol., 62: 529 
$-534,1986$.

13) Sniecinski, I., O'Donnell, M.R., Nowicki, B. and Hill, L.R.: Prevention of refractoriness and HLA-alloimmunization using filtered blood products. Blood, 71 : 1402-1407, 1988.

14) Andreu, G., Dewailly, J., Leberre, C., et al.: Prevention of HLA immunization with leukocyte-poor packed red cells and plateletes obtained by filtration. Biood, 72: 964-969, 1988.
15) Fisher, M., et al.: Vox Sang, 49: 331-335, 1985.

16) Snyder, E.L.: Clinical use of white cell-poor blood components. Transfusion, 29: 568-571, 1989.

17) Saarinen, U.M., Kenomaki, R., Siimes, M.A. and Myllylla, G.: Effective prophylaxis against platelet refractoriness in multitransfused patients by use of leukocyte-free blood components. Blood, 75 : 512-517, 1990. 